\title{
Reversal by Cyclic AMP of the Urea-induced Inhibition of Synthesis of a Catabolite-repressible Enzyme in Vibrio cholerae
}

\author{
By DHRUBAJYOTI CHAKRAVARTI AND AMIT GHOSH* \\ Indian Institute of Chemical Biology, Jadavpur, Calcutta 700 032, India
}

(Received 10 February 1987; revised 6 July 1987)

\begin{abstract}
Low concentrations of urea, which did not inhibit the synthesis of the catabolite nonrepressible enzyme alkaline phosphatase in Vibrio cholerae, or markedly affect its overall growth, specifically inhibited the expression of the tryptophanase operon in a temperature-dependent manner. However, in contrast to what is found in Escherichia coli, this urea-induced inhibition of tryptophanase synthesis in $V$. cholerae could be almost completely relieved by exogenously added cyclic AMP. The possible mechanism of the process is discussed.
\end{abstract}

\section{INTRODUCTION}

Many enzymes responsible for the catabolism of carbon compounds in a variety of microorganisms are repressed by glucose or its degradation products. This phenomenon, known as catabolite repression (Magasanik, 1961), has been demonstrated in many organisms to be mediated through the intracellular level of cyclic $3^{\prime}: 5^{\prime}$-adenosine monophosphate (cAMP) (Zubay, 1980). Enzymes whose synthesis is subject to catabolite repression are termed catabolite-repressible. In Escherichia coli various agents such as urea (Sanzey \& Ullmann, 1976, 1980), nitrofurans (Herrlich \& Schweiger, 1976), intercalating dyes (Sankaran \& Pogell, 1973), gyrase-specific drugs (Sanzey, 1979) and phages (Ghosh et al., 1985a) can preferentially inhibit the synthesis of catabolite-repressible enzymes. All these agents except urea, however, severely inhibit growth at the concentrations used. Urea, which exerts its effect at the level of transcription at the concentrations used, affects the expression of catabolite-repressible operons without interfering with overall cellular metabolism and thus truly mimics physiological catabolite repression (Sanzey \& Ullmann, 1980). However, unlike physiological catabolite repression, the repression exerted by urea is not antagonized by cAMP (Sanzey \& Ullmann, 1980). This observation, along with other observations - that catabolite repression can persist in the presence of cAMP (Wanner et al., 1978) for example -- has led to a reappraisal of the theory of catabolite repression (Ullmann \& Danchin, 1983). Even though much information is available on the mechanism of catabolite repression in E. coli, very little is known about the process in other organisms. It has, however, been found that in many organisms catabolite repression is not mediated through cAMP (Phillips \& Mulfinger, 1981; Price \& Gallant, 1983; Roberts \& Morse, 1978; Eraso \& Gancedo, 1984).

In our laboratory we are studying the regulation of gene expression in Vibrio cholerae. We have discovered the existence of SOS functions in this organism (Siddiqui \& Ghosh, 1983) and the involvement of a rec $A$-like gene in these processes (Ghosh et al., 1985b). We have also shown that alkaline phosphatase in $V$. cholerae is not subject to catabolite repression and that its synthesis, in contrast to what is found in $E$. coli, is actually stimulated by glucose (Mitra $e t$ al., 1986). In this paper we show that as in $E$. coli, in $V$. cholerae also, urea preferentially inhibits the synthesis of catabolite-repressible enzymes but that unlike in $E$. coli this urea-induced repression is almost completely antagonized by cAMP. We believe that this is the first report of a DNA-

Abbreviation: CRP, cAMP receptor protein.

0001-3996 C 1987 SGM 
denaturing agent interfering with the cAMP-dependent form of catabolite repression in any organism.

\section{METHODS}

Bacterium. Vibrio cholerae strain Inaba 569B used in this study was obtained from the National Institute of Cholera and Enteric Diseases, Calcutta. Cultures were stored and maintained as described by Mitra et al. (1986).

Media. Nutrient broth ( $\mathrm{pH} 8.0$ ) contained per litre: $10 \mathrm{~g}$ peptone (Difco), $10 \mathrm{~g}$ Lab-Lemco powder (Oxoid), $5 \mathrm{~g}$ $\mathrm{NaCl}$. Modified M9 (MM9) medium contained per litre: $9 \mathrm{~g} \mathrm{Na}_{2} \mathrm{HPO}_{4}, 1 \mathrm{~g} \mathrm{KH}_{2} \mathrm{PO}_{4}, 1 \mathrm{~g} \mathrm{NH}_{4} \mathrm{Cl}, 10 \mathrm{~g} \mathrm{NaCl}$, $14.7 \mathrm{mg} \mathrm{CaCl} 2.2 \mathrm{H}_{2} \mathrm{O}, 246.5 \mathrm{mg} \mathrm{MgSO}_{4} \cdot 7 \mathrm{H}_{2} \mathrm{O}, 500 \mathrm{mg}$ vitamin-free Casamino acids (Difco), $0.2 \mathrm{mg}$ vitamin $\mathrm{B}_{1}$ and $10 \mathrm{ml} 99 \%(\mathrm{v} / \mathrm{v})$ glycerol or $5 \mathrm{~g}$ sodium succinate; $\mathrm{pH} 8.0$. Low-phosphate Tris/glucose (LPTG) medium contained per litre: $12 \mathrm{~g}$ Tris, $1 \mathrm{~g} \mathrm{NH}_{4} \mathrm{Cl}, 10 \mathrm{~g} \mathrm{NaCl}, 35 \mathrm{mg} \mathrm{KCl}, 2.7 \mathrm{mg} \mathrm{FeCl}{ }_{3} .6 \mathrm{H}_{2} \mathrm{O}, 246 \mathrm{mg} \mathrm{MgSO}_{4} .7 \mathrm{H}_{2} \mathrm{O}$, $1 \mathrm{mg} \mathrm{KH} \mathrm{PO}_{4}, 500 \mathrm{mg}$ vitamin-free Casamino acids (Difco) and $4 \mathrm{~g}$ glucose; $\mathrm{pH} 8.0$ (adjusted with $\mathrm{HCl}$ ). The composition of the high-phosphate Tris/glucose (HPTG) medium was the same as LPTG except that it contained $400 \mathrm{mg} \mathrm{KH} \mathrm{PO}_{4} 1^{-1}$.

Growth and adaptation of cells in synthetic media. For cell growth in synthetic media, early exponential phase cells growing in nutrient broth were harvested by centrifugation, washed twice with prewarmed synthetic medium and then resuspended in 20 vols of the same medium. After $12 \mathrm{~h}$ growth at $37^{\circ} \mathrm{C}$ with shaking, a $0.1 \mathrm{ml}$ sample was withdrawn and inoculated into $20 \mathrm{ml}$ of the same medium prewarmed to $37^{\circ} \mathrm{C}$. This culture was then grown with shaking at $37^{\circ} \mathrm{C}$ for a further period of $12 \mathrm{~h}$. A sample from the above was diluted 25 -fold into fresh medium and grown with shaking at a defined temperature. Induction or derepression of the enzymes was initiated when the culture reached the mid-exponential phase of growth $\left(2 \times 10^{8}\right.$ cells $\left.\mathrm{ml}^{-1}\right)$.

Dry weight of bacteria was determined essentially according to Hadjipetrou et al. (1964) with a minor modification - cells were washed with $0.154 \mathrm{M}-\mathrm{NaCl}$ instead of distilled water.

Induction of enzymes and assay. Tryptophanase was induced by adding DL-tryptophan to mid-exponential phase cells growing in MM9 medium, at a final concentration of $1 \mathrm{mg} \mathrm{m}^{-1}$. The enzyme was assayed according to Bilezikian et al. (1967). Under this condition of assay cAMP inhibits tryptophanase activity by $15 \%$ (Pastan \& Perlman, 1969; our unpublished observation). This was taken into account whenever cAMP was present in the reaction mixture. One unit $(\mathrm{U})$ of enzyme activity was defined as the amount of enzyme that liberated $1 \mathrm{nmol}$ indole $\min ^{-1}$ at $37^{\circ} \mathrm{C}$ and $\mathrm{pH} 8 \cdot 0$. Percentage inhibition of the differential rate of tryptophanase synthesis in the presence of urea or glucose was calculated according to Yudkin (1969). To initiate the derepression of alkaline phosphatase, a mid-exponential phase culture of $V$. cholerae growing in HPTG was harvested by centrifugation, washed twice with prewarmed LPTG and then resuspended in an equal volume of the same medium. Samples were withdrawn at defined intervals and assayed for alkaline phosphatase as described by Ghosh \& Poddar (1977). One unit (U) of enzyme activity was defined as the amount of enzyme that liberated $1 \mathrm{pmol} p$-nitrophenol $\mathrm{min}^{-1}$ at $37^{\circ} \mathrm{C}$ and $\mathrm{pH} 8.3$.

Experiments reported in this paper were done at least three to five times. Representative results are shown.

\section{RESULTS}

\section{Effect of urea on the synthesis of catabolite-repressible and catabolite-nonrepressible enzymes}

Urea at concentrations ranging from 0.2 to $0.6 \mathrm{M}$ added to a culture of $V$. cholerae 569B, growing exponentially in synthetic medium with glycerol or succinate as the carbon source, affected the differential rate of tryptophanase synthesis quite severely. The higher the concentration of urea in the growth medium, the more severe was the repression (Fig. $1 b$ ). However, at these concentrations urea had only a slight effect on growth (Fig. 1 $a$ ). It also did not affect the synthesis of the catabolite-nonrepressible enzyme alkaline phosphatase (Fig. 2). Thus urea at a concentration of $0.4 \mathrm{~m}$ specifically repressed the synthesis of the catabolite-repressible enzyme tryptophanase but did not appreciably affect either the growth of the cells or the synthesis of the catabolite-nonrepressible enzyme alkaline phosphatase. This effect was similar to that found in $E$. coli. That urea produced its effect by restricting the entry of inducer molecules was ruled out from the fact that urea at a given concentration produced an identical level of inhibition when the inducer concentration was varied from 0.5 to $5 \mathrm{mg} \mathrm{m}^{-1}$ and also from the fact that cells grown in the presence of urea exhibited a lower basal level of enzyme, in the absence of exogenously added inducer (data not shown). 


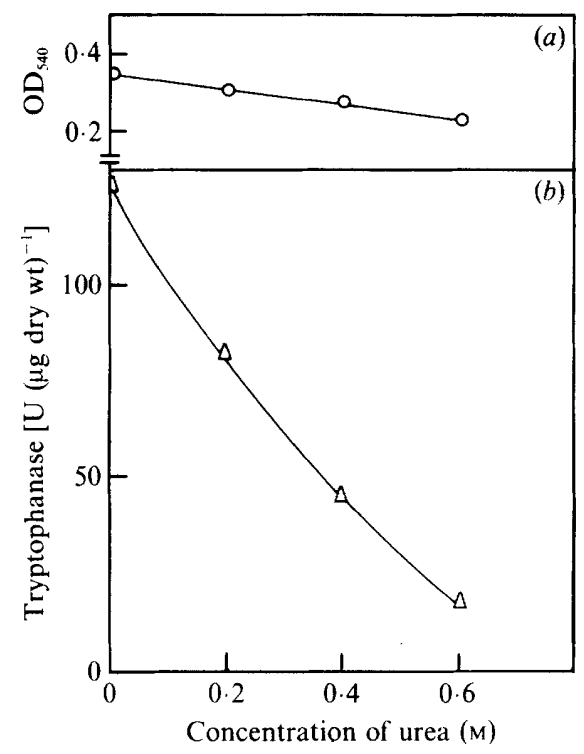

Fig. 1

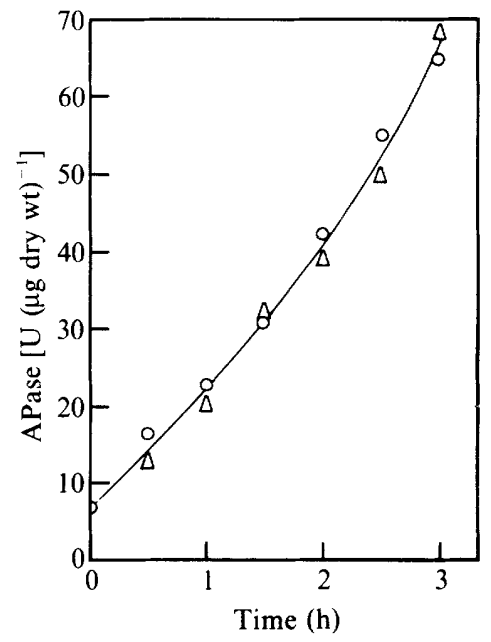

Fig. 2

Fig. 1. Synthesis of tryptophanase in $V$. cholerae in the presence of increasing concentrations of urea. Exponentially growing cells were incubated with $1 \mathrm{mg}$ DL-tryptophan $\mathrm{ml}^{-1}$ and increasing concentrations of urea for $90 \mathrm{~min}$ at $37^{\circ} \mathrm{C}$ with shaking. Samples were removed at the end of the induction period and assayed for tryptophanase $(\triangle)$. Growth $(O)$ was estimated by measuring the optical density at $540 \mathrm{~nm}$ (initial $\mathrm{OD}_{540}=0 \cdot 15$ ).

Fig. 2. Effect of $0.4 \mathrm{M}$-urea on alkaline phosphatase (APase) synthesis in V. cholerae. Cells growing in HPTG were harvested by centrifugation, washed twice with prewarmed LPTG, then incubated with shaking at $37^{\circ} \mathrm{C}$ in the same medium in the absence $(O)$ or presence $(\triangle)$ of $0.4 \mathrm{M}$-urea. Samples were removed at various times to monitor growth of cells and for the assay of APase.

\section{Effect of cAMP}

The effect produced by urea was reminiscent of that produced by glucose on the synthesis of catabolite-repressible enzymes. Glucose at $0.017 \mathrm{M}$ (i.e. $0.3 \%$, w/v) exerted strong catabolite repression on the synthesis of tryptophanase in $V$. cholerae and this repression could be alleviated by CAMP. Maximum relief was obtained at cAMP concentrations of $5 \mathrm{mM}$ or higher (Fig. $3 b$ ). When added to cultures growing in the presence of $0.4 \mathrm{M}$-urea, cAMP was able to reverse urea-induced catabolite repression also (Fig. $3 a$ ). The extent of reversal obtained with different concentrations of cAMP was similar irrespective of whether glucose or urea was causing the catabolite repression. cAMP at concentrations of $5 \mathrm{mM}$ or higher almost completely reversed the catabolite repression of tryptophanase synthesis induced by either agent.

\section{Effect of urea at different temperatures}

The mechanism of urea-induced inhibition of the synthesis of catabolite-repressible enzymes in $V$. cholerae was thus different from that found in $E$. coli. In $E$. coli, glucose- and urea-induced inhibition of the synthesis of catabolite-repressible enzymes, although phenomenologically very similar, are mechanistically very different: glucose repression operates via the cAMP receptor protein (CRP)-cAMP system (Zubay, 1980), whereas urea-induced inhibition does not (Sanzey $\&$ Ullmann, 1980). The results described in the preceding section indicated that in $V$. cholerae not only glucose repression but also the urea-induced repression is regulated through the mediation of cAMP. To investigate the extent of this resemblance, urea-induced catabolite repression of tryptophanase was examined at 30,37 and $42{ }^{\circ} \mathrm{C}$. The percentage inhibition of the differential rate of enzyme synthesis after the addition of $0.4 \mathrm{M}$-urea was $60 \%$ at $42{ }^{\circ} \mathrm{C}$ as against 


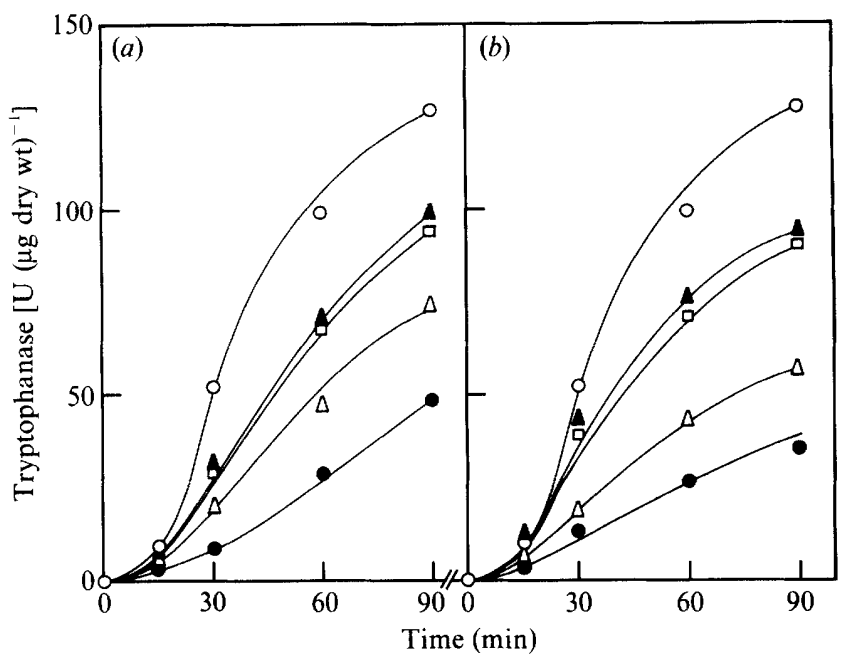

Fig. 3. Reversal by cAMP of the urea- or glucose-induced catabolite repression of tryptophanase. (a) Exponentially growing $V$. cholerae cells in MM9 medium were induced with $1 \mathrm{mg}$ DL-tryptophan ml $\mathrm{m}^{-1}$ at $37^{\circ} \mathrm{C}$ in the absence of urea (O), or in the presence of $0.4 \mathrm{M}$-urea (O), $0.4 \mathrm{M}$ urea plus $1 \mathrm{mM}$-cAMP $(\triangle), 0.4 \mathrm{M}$-urea plus $5 \mathrm{mM}$-cAMP $(\square)$ or $0.4 \mathrm{M}$-urea plus $10 \mathrm{mM}$-cAMP $(\mathbf{\Delta})$. (b) As for $(a)$, except that $0.017 \mathrm{M}$-glucose was used in place of $0.4 \mathrm{M}$-urea.

$40 \%$ and $46 \%$ at $37{ }^{\circ} \mathrm{C}$ and $30{ }^{\circ} \mathrm{C}$ respectively. Glucose exerts identical repression over this range of temperature both in E. coli (Marr et al., 1964) and in V. cholerae (data not shown).

\section{DISCUSSION}

The experiments described in this paper show that as in E. coli, in $V$. cholerae also, low concentrations of urea which do not appreciably interfere with growth or with the synthesis of catabolite-nonrepressible enzymes, specifically inhibit the expression of catabolite-sensitive operons. But unlike in E. coli, cAMP antagonizes urea-induced inhibition of enzyme synthesis in V. cholerae.

Sanzey \& Ullmann (1980) have shown that in E. coli urea produces its effect mainly by interfering with the initiation of transcription at the promoters of catabolite-sensitive operons. Although we have no direct evidence to show that this is the case in $V$. cholerae also, the very fact that the urea effect can be antagonized by cAMP points towards a similar mechanism. In all organisms studied so far the target for CRP-cAMP action is the promoter region of the catabolite-sensitive operons. Inhibitory effects produced by urea appear to depend on the structure of the promoter region, since both in $E$. coli and in $V$. cholerae, urea affects only the expression of catabolite-sensitive operons. One of the main differences between the promoters of catabolite-sensitive and catabolite-insensitive operons is that in the former, RNA polymerase cannot initiate transcription without assistance from the CRP-cAMP complex (Rosenberg \& Court, 1979; de Crombrugghe et al., 1984). Even though it is not properly understood how CRP assists RNA polymerase (Malan et al., 1984), one model is that in the CRP-dependent promoters RNA polymerase by itself cannot accomplish the initial melting of the DNA necessary for the initiation of transcription (Dickson et al., 1975). Relevant to this model is the observation that mutation in the gene coding for topoisomerase I releases the dependence of these operons on CRP (Sternglanz et al., 1981).

It is thus probable that urea produces its effect by somehow affecting the binding of CRP to its sites on the DNA. Although the presence of the canonical sequence (--AANTGTGANNT--NCANATT---) (de Crombrugghe et al., 1984) is necessary for the binding of CRP-cAMP complex to the specific DNA sites, there is some evidence that the affinity of CRP (and hence 
the CRP-cAMP complex) for the DNA site is determined to some extent by the local DNA topology (Ullmann \& Danchin, 1983). In vitro studies with defined promoter regions of $E$. coli have shown that the concentration of CAMP required for the optimal binding of CRP molecules to its DNA sites varies from site to site and the higher the concentration of cAMP required, the worse is the site (Kolb et al., 1983). In vivo also it has been observed that different catabolitesensitive operons in $E$. coli require different amounts of cAMP for their expression (Lis \& Schlief, 1973; Piovant \& Lazdunski, 1975). In vitro, urea acts on the DNA by stabilizing the coiled denatured DNA without affecting the opening of the double helix (Levine et al., 1963). If in vivo urea acts on the DNA as it does in vitro, then it could produce its effect by freezing the CRP-binding site on the DNA in a non-optimal conformation such that an efficient CRPbinding site is converted into an inefficient one. In the presence of the amount of cAMP normally present in $V$. cholerae cells growing in MM9 medium, CRP may not be able to bind efficiently to this 'modified' site. However, in the presence of excess CAMP, CRP (and hence the CRP-cAMP complex) may still be able to bind to this site and thereby reverse the urea-induced effect.

One prediction of this hypothesis, which provides a plausible explanation for the observations reported in this paper, is that an increase in temperature should lead to an enhancement of the urea-induced inhibition. This is expected because DNA molecules 'breathe' and the probability of this process increases with temperature (Vologodskii et al., 1979). Our observation that inhibition of enzyme synthesis is greater at $42^{\circ} \mathrm{C}$ than at 30 or $37^{\circ} \mathrm{C}$ lends credence to this hypothesis. However, the slightly higher level of repression obtained at $30^{\circ} \mathrm{C}$ compared with that at $37^{\circ} \mathrm{C}$ indicates that the hypothesis elaborated above cannot wholly account for the observed urea effect and that other processes may also be involved.

In conclusion, our results show that agents that can preferentially inhibit the expression of catabolite-sensitive genes in $E$. coli can also do so in other organisms. However, the underlying mechanism of action is not uniform. Thus while in $E$. coli urea interferes with the cAMPindependent form of repression (Guidi-Rontani et al., 1980), in $V$. cholerae the urea-induced inhibition of the synthesis of catabolite-repressible enzymes is mediated through the CRPcAMP system.

\section{REFERENCES}

Bilezikian, J. P., Kaempfer, R. O. R. \& Magasanik, B. (1976). Mechanism of tryptophanase induction in Escherichia coli. Journal of Molecular Biology 27, 495506.

de Crombrugghe, B., Busby, S. \& Buc, H. (1984). Cyclic AMP receptor protein: role in transcription activation. Science 224, 831-838.

Dickson, R. C., Abelson, J., Barnes, W. M. \& REZNIKOFF, W. S. (1975). Genetic regulation: the lac control region. Science 187, 27-35.

ERaso, P. \& Gancedo, J. M. (1984). Catabolite repression in yeasts is not associated with low levels of cAMP. European Journal of Biochemistry 141, 195198.

Ghosh, A. \& PoDdar, R. K. (1977). Reduced synthesis of $\beta$-galactosidase in Escherichia coli infected with phage $\Phi$ X174. Canadian Journal of Microbiology 23, 1069-1077.

Ghosh, A., Pal, S. K. \& Poddar, R. K. (1985a). Modulation of gene expression in Escherichia coli infected with single stranded bacteriophage $\Phi \times 174$. Molecular and General Genetics 198, 304-308.

Ghosh, R. K., Siddiqui, K. A. I., Mukhopadhyay, G. \& GHOSH, A. (1985b). Evidence that a system similar to the recA system of Escherichia coli exists in Vibrio cholerae. Molecular and General Genetics 200, 439441.

Guidi-Rontani, C., Danchin, A. \& UllmanN, A.
(1980). Catabolite repression in Escherichia coli mutants lacking cyclic AMP receptor protein. Proceedings of the National Academy of Sciences of the United States of America 77, 5799-5801.

Hadjipetrou, L. P., Gerrits, J. P., Teulings, F. A. G. \& Stouthamer, A. H. (1964). Relation between energy production and growth of Aerobacter aerogenes. Journal of General Microbiology 36, 139 150.

HeRRLICH, P. \& SCHWEIGER, M. (1976). Nitrofurans, a group of synthetic antibiotics, with a new mode of action: discrimination of specific messenger RNA classes. Proceedings of the National Academy of Sciences of the United States of America 73, 33863390.

Kolb, A., Spassky, A., Chapon, C., Blazy, B. \& Buc, H. (1983). On the different binding affinities of CRP at the lac, gal and malT promoter regions. Nucleic Acids Research 11, 7833-7852.

LEVINE, L., GoRdon, J. A. \& JeNCKs, W. P. (1963). The relationship of structure to the effectiveness of denaturing agents for deoxyribonucleic acid. Biochemistry 2, 168-175.

LIS, J. T. \& SCHLIEF, R. (1973). Different cyclic AMP requirements for induction of the arabinose and lactose operons of Escherichia coli. Journal of Molecular Biology 79, 149-162.

Magasanik, B. (1961). Catabolite repression. Cold 
Spring Harbor Symposia on Quantitative Biology 26, 249-256.

Malan, T. P., Kolb, A., Buc, H. \& McClure, W. R. (1984). Mechanism of CRP-cAMP activation of lac operon transcription initiation: activation of the $\mathrm{P} 1$ promoter. Journal of Molecular Biology 180, 881909.

MarR, A. G., Ingraham, J. L. \& SQuires, C. L. (1964). Effect of the temperature of growth of Escherichia coli on the formation of $\beta$-galactosidase. Journal of Bacteriology 87, 356-362.

Mitra, S., Ghosh, A. \& Ghosh, R. K. (1986). Metabolic reactions responsible for glucose stimulation of alkaline phosphatase in Vibrio cholerae. Journal of General Microbiology 132, 2601-2603.

Pastan, I. \& Perlman, R. L. (1969). Stimulation of tryptophanase synthesis in Escherichia coli by cyclic $3^{\prime}, 5^{\prime}$-adenosine monophosphate. Journal of Biological Chemistry 244, 2226-2232.

Phillips, A. T. \& Mulfinger, L. M. (1981). Cyclic adenosine 3',5'-monophosphate levels in Pseudomonas putida and Pseudomonas aeruginosa during induction and carbon catabolite repression of histidine synthesis. Journal of Bacteriology 145, 12861292.

Piovant, M. \& Lazdunski, C. (1975). Different cyclic adenosine $3^{\prime}, 5^{\prime}$-monophosphate requirements for induction of $\beta$-galactosidase and tryptophanase. Effect of osmotic pressure on intracellular cyclic adenosine 3',5'-monophosphate concentrations. Biochemistry 14, 1821-1825.

Price, V. L. \& Gallant, J. A. (1983). The glucose effect in Bacillus subtilis. European Journal of Biochemistry 134, 105-107.

RoberTS, C. T., JR \& MORSE, D. E. (1978). Genetic regulation of galactokinase in Tetrahymena by cyclic AMP, glucose and epinephrine. Proceedings of the National Academy of Sciences of the United States of America 75, 1810-1814.

ROSENBERG, M. \& COURT, D. (1979). Regulatory sequences involved in the promotion and termination of RNA transcription. Annual Review of Genetics 13, 319-353.
Sankaran, L. \& Pogell, B. M. (1973). Differential inhibition of catabolite sensitive enzyme induction by intercalating dyes. Nature New Biology 245, 257260.

SANZEY, B. (1979). Modulation of gene expression by drugs affecting deoxyribonucleic acid gyrase. Journal of Bacteriology 138, 40-47.

SANZEY, B. \& UllmanN, A. (1976). Urea, a specific inhibitor of catabolite sensitive operons. Biochemical and Biophysical Research Communications 71, 10621068.

Sanzey, B. \& Ullmann, A. (1980). The effect of urea on catabolite sensitive operons in Escherichia coli K12. Molecular and General Genetics 178, 611-616.

Siddiqui, K. A. I. \& GHosH, A. (1983). Temperate phage induction and filament formation in Vibrio cholerae by furazolidone. Biochemical and Biophysical Research Communications 112, 1106-1111.

Sternglanz, R., Dinardo, S., Voelkel, K. A., Nishimura, Y., Hirota, Y., Bechierer, K., ZuMSTEIN, L. \& WANG, J. C. (1981). Mutations in the gene coding for Escherichia coli DNA topoisomerase I affect transcription and transposition. Proceedings of the National Academy of Sciences of the United States of America 78, 2741-2751.

Ullmann, A. \& Danchin, A. (1983). Role of cyclic AMP in bacteria. In Advances in Cyclic Nucleotide Research, vol. 15, pp. 1-53. Edited by P. Greengard \& G. A. Robison. New York: Raven Press.

VologodskiI, A. V., LuKashin, A. B., ANSHEleVICH, V. V. \& Frank-Kamenetskil, M. D. (1979). Fluctuations in superhelical DNA. Nucleic Acids Research 6, 967-982.

Wanner, B. L., Kodaira, R. \& Neidhardt, F. C. (1978). Regulation of lac operon expression: reappraisal of the theory of catabolite repression. Journal of Bacteriology 136, 947-954.

YUDKIN, M. D. (1969). Catabolite repression of the lac operon: the contribution of transcriptional repression. Biochemical Journal 114, 307-311.

ZUBAY, G. (1980). Regulation of transcription in prokaryotes, their plasmids and viruses. Cell Biology 3, $154-214$. 